\title{
VIVÊNCIAS MATERNAIS EM UNIDADE DE TERAPIA INTENSIVA: um olhar fenomenológico
}

\author{
Regina Lúcia Ribeiro Moreno* \\ Maria Salete Bessa Jorge** \\ Rui Verlaine de Oliveira Moreira***
}

\section{Resumo}

Trata-se de uma pesquisa fenomenológica na perspectiva de Martin Heidegger realizada com oito mães acompanhantes, com objetivo de compreender as vivências maternais na UTI do Hospital Infantil Albert Sabin, Fortaleza-CE. As informações foram obtidas pela entrevista fenomenológica, contendo a pergunta-guia: como se mostra a você ser mãe em uma UTI e vivenciar a maternagem nesta unidade hospitalar? Submetidas à análise do fenômeno situado, proposta por Martins e Bicudo. Nas vivências as mães revelaram segurança e medo, esperança e angústia, potencialidades e impotência, preocupações existenciais e expectativas de ser no mundo. Além desses aspectos, as mães revelaram-se como seres autênticos que se libertaram da ocupação, indo ao encontro da pré-ocupação.

Descritores: fenomenologia; vivência maternal; UTI

\begin{abstract}
This is a phenomenological research in Martin Heidegger's perspective with eight mothers staying with their babies in the hospital, with the aim of understanding their maternal feelings at the ICU of the Albert Sabin Infant Hospital in Fortaleza-CE. The information was obtained by means of phenomenological interviews with the following probing question, "What is it like for you as a mother to be in an ICU and at the same time follow all that goes on in the hospital unit?" and submitted to the analysis of the phenomena sited as proposed by Martins and Bicudo. The experiences of the mothers revealed safety and fear, hope and anguish, potentialities and impotence, existential concerns and expectations of a human being in the world. Beyond these aspects, the mothers showed themselves to be authentic people that got free of the occupation and deal with the pre-occupation.
\end{abstract}

Descriptors: Phenomenology, Maternal Experiences, ICU

Title: Experiences of mothers with babies in intensive care units: a phenomenological perspective

\section{Resumen}

Se trata de una investigación fenomenológica bajo la perspectiva de Martín Heidegger. Ocho madres que estaban como acompañantes en la Unidad de Tratamiento Intensivo del Hospital Infantil Albert Sabin, en Fortaleza, fueron entrevistadas para recoger sus opiniones sobre sus vivencias maternales. La pregunta-guía del trabajo fue: cómo es ser madre en una UTI y vivenciarlo en esa unidad del Hospital. Los resultados muestran que las madres experimentan seguridad y miedo, esperanza y angustia, potencialidades e impotencia, preocupaciones existenciales y perspectivas de ser en el mundo. Además, se revelan seres auténticos, que se libertaron de la ocupación y van hacia un encuentro con una preocupación.

Descriptores: fenomenología; vivencia maternal; UTI

Titulo: Vivencias maternales en unidad de terapia intensiva: una mirada fenomenológica

\section{Introdução}

A preocupação com o mundo vivencial de mães acompanhantes em Unidade de Terapia Intensiva (UTI) e a escolha do tema surgem após experienciarmos a prática profissional no Centro de Terapia Intensiva do Hospital Infantil Albert Sabin (HIAS). Infelizmente, percebemos que a ação terapêutica permanece ainda mais voltada para o corpo biológico, esquecendo-se, muitas vezes, da construção simbólica, fundamental para a existência do ser-no-mundo Acreditamos, no entanto, que a realidade vivida por essas mães vem passando por modificações com o processo de humanização. A humanização tem sido fator presente, demonstrando o novo rumo que o cuidado vem assumindo nos últimos anos ${ }^{(1)}$. A descoberta do modo como acontece o exercício da maternidade no cenário das UTI's nasce, portanto, como proposta deste estudo e só poderá ser revelada após a compreensão da vivência materna, no cotidiano de seu mundovida, pois de nada adianta tentar descobrir as causas dos pensamentos, sentimentos, percepções e/ou comportamentos de mães acompanhantes, se não houver a preocupação de dar-lhes voz, para que possamos penetrar em seu mundo e revelar o que ali se encontra velado e não o que parece e aparece. A pergunta-guia é Como se mostra a você, ser mãe em uma UTI e vivenciar a maternagem nesta unidade hospitalar? Tal indagação norteadora busca compreender o que é essencial e invariante para que possamos chegar à sua essência e abrir caminhos para uma assistência mais humanizante e integradora nas UTI's. Esse encaminhamento aproxima-se da fenomenologia ao investigar a verdade tomada por base na vivência materna na UTI, e tem como objetivos: a) compreender as experiências maternais em UTI; b) conhecer o modo como a mãe acompanha seu filho enfermo nesta unidade hospitalar, pois a fenomenologia proporciona o conhecimento do outro e do mundo, ao favorecer o estabelecimento da relação entre sujeito-objeto(2).

\section{Caminho Metodológico}

A pesquisa foi desenvolvida a partir de março de 2002, em Fortaleza-CE, no Hospital Infantil Albert Sabin, com oito mães acompanhantes, após ter sido aprovada pelos Comitês de Ética em Pesquisa da UECE e da Instituição envolvida, conforme determinações da Resolução 196/96 do Ministério da Saúde ${ }^{(3)}$. Fundamentou-se em categorias heideggerianas teóricas e, como método de organização e interpretação das informações, arrimou-se nas categorias de análise de Martins e Bicudo, isto é análise ideográfica e nomotética(4), na busca de melhor conhecer o mundo experimental e cultural dessas mães, denominada também fenômeno situado ou fenomenologia existencial, pois busca um melhor acesso ao mundo-vida dos sujeitos envolvidos, descobrindo o não-dito contido em forma simbólica para chegar à objetividade e des-velar o objeto de estudo. Os critérios de inclusão dos sujeitos, na constituição

* Terapeuta Ocupacional. Membro da Comissão de Ética em Pesquisa do Hospital Infantil Albert Sabin. Coordenadora do Projeto Mão Amiga do HIAS. Mestre em Saúde da criança e do adolescente pela UECE.

** Enfermeira. Professora Doutora em Enfermagem. Titular da Enfermagem em Saúde Mental da UECE. Líder do Grupo de Pesquisa em Saúde Mental, Família e Práticas de Saúde.

*** Filósofo. Professor Doutor titular da UFC-CE, Departamento de Direito Processual da UFC

E-mail do autor: reginamoreno@secrel.com.br 
dos participantes da pesquisa, foram aceitabilidade e acompanhamento materno na UTI. A entrevista fenomenológica contendo a questão - Como se mostra a você ser mãe em uma UTI e vivenciar a maternagem nessa unidade hospitalar?- fezse presente, como técnica de obtenção de informações, após assinatura do Termo de Consentimento Livre e Esclarecido, por possibilitar melhor aproximação dos dados vivenciais da mãe acompanhante, os quais em tempo algum, poderiam ser quantificados na lógica do conhecimento científico cartesiano, pelo fato de relatar a subjetividade humana, impossível de ser mensurada, calculada, controlada e/ou precisada, como os aspectos objetivos de uma pesquisa científica tradicional. Alguns dados pessoais da mãe foram também coletados para elucidar o seu modo de ser e esculpir os mais belos detalhes deste fenômeno.

\subsection{O Modo de ser da mãe acompanhante Na UTI}

As unidades de significado -Ser-mãe na UTI, Real vivido no mundo da UTI, Sentimentos e emoções, Aspectos relacionais (Ser-com na UTI)- foram trabalhadas visando a obter as convergências das unidades dos discursos que compõem a configuração das asserções gerais, importantes para desvelar a estrutura do fenômeno: Vivências maternais na UTI. Ser-mãe na UTI refletem cuidar e, ainda, repercussões de atos maternais junto ao bebê enfermo. Analisando a convergência dos discursos com fundamento no referencial filosófico de Martin Heidegger, podemos asseverar que Ser-mãe na UTI implica solicitude, presença, preocupação e cuidado.

\subsubsection{Solicitude}

A solicitude é a forma de o ser relacionar-se com o outro, de cuidar da existência do outro, ou ainda oferecer condições ao outro de cuidar-se. A solicitude ou maneira de cuidar do outro geralmente só se faz possível, mediante a relação envolvente e significante, cujos ingredientes básicos são consideração e paciência com o outro, podendo apresentar-se como cuidado dominador, manipulador, onde tudo é feito pelo outro, ou cuidado que possibilita ao outro crescer, descobrir-se e assumir o próprio caminho(5). Ser-mãe para os sujeitos desta pesquisa é dar força pro bebê, pra ele reagir mais rápido (M1). Dar carinho, amor. Cuidar da minha filha, saber se ela tá reagindo, aceitando a dieta. Porque ela precisa muito (M2). Tá ali do lado, apoiando, quando vão pegar uma veia (M7).

\subsubsection{Pre-sença (Dasein)}

A pre-sença, que é o ente que sempre eu mesmo sou, dificilmente ocorre isoladamente. Um ser ou modo de ser caracteriza-se pelo estar com o outro. E é nesta co-pre-sença que o homem constrói a sua existência, a sua história. Todo ser é sempre ser-com, mesmo na solidão e isolamento. A presença é sempre co-pre-sença. Nesta pesquisa, estar presente parece significar estar perto, estar em comunhão com o filho, mantendo vivos os laços de afeto construídos ao longo da gravidez. A essência da presença implica compreensão do ser dos outros entes no mundo, além da compreensão do Ser-aí e do mundo, isoladamente, pois o mundo da presença é sempre um mundo compartilhado com os outros e o viver é sempre convivência ${ }^{(6)}$. É ficar ao lado dela, ao redor dela, pra quando ela precisar de mim, eu estar perto dela (M2). Acho que eu tando lá, perto dela, falando com ela, fazendo carinho, ela melhora um pouco mais rápido (M3). É passar carinho, segurar na mãozinha, conversar, dar muito apoio e força, Assim ela vai se sentir mais segura. Sentindo que não tá sozinha, que a mãe dela tá lá e gosta muito dela (M7).

\subsubsection{Pré-ocupação}

A análise existencial de Heidegger mostra que a préocupação responde aos aspectos ontológicos do ser, chegando à autenticidade, por transcender o momento ôntico da inautenticidade, modos do homem se manifestar em sua existência. Pré-ocupação é ocupar-se, como instituição social de fato, sem preencher todo um significado no mundo(6). O ser por um outro, contra um outro, sem os outros, o passar ao lado um do outro, o não sentir-se tocado pelos outros são modos deficientes de pré-ocupação, que caracterizam a convivência, e não a constituição ontológica da pre-sença como ser-com. Preocupar-se para os sujeitos envolvidos é ficar com o bebê ,dar atenção. É conversar com ele pra se fazer perceber. É observar o que está sendo feito (M1). É dar carinho, amor, tocar nele, ficar do lado, saber se ele tá reagindo, aceitando a dieta [...] (M2). É estar junto do filho, falar com ele, dar carinho, força, passar a mão (M3). [...] É nervosismo, expectativa, estresse, preocupação. É tudo (M5).

\subsection{Cuidado}

O cuidado materno, atividade com a qual se ocupam as mães acompanhantes, é geralmente explicitado sob um prisma existencial, eficiente para promover saúde e crescimento, alívio da dor ou até facilitar a cura. O cuidado é visto pelos participantes desse estudo, portanto, como um constitutivo do sujeito e não como algo exterior a ele. O cuidado no entanto, pode ser entendido ainda, como algo a mais do que um simples ato; uma atitude que, do ponto de vista existencial, se encontra na constituição ontológica do $\operatorname{ser}^{(7)}$. Nos discursos, as mães discorrem sobre as possibilidades e/ou dificuldades de cuidado na UTI, e ainda sobre o significado desta prática para ela e para o seu bebê enfermo. Tô de licença pra ficar com o M. Ele precisa de cuidado, de atenção especial (M1). Você fica com aquela vontade de pegar, de cuidar, banhar, fazer todas aquelas coisas (M8).

A mãe acompanhante é um Ser-aí de sentimentos e preocupações, que se revela como um ser que cuida, mas que também precisa de cuidados. É aquela que age e reage movida pelos encargos do cuidado ao ser lançada no mundo da UTI. E vivencia, de forma explicita ou não, aspectos existenciais, revelando, consciente ou inconscientemente, os significados que atribui à maternagem na UTI.

Observando os discursos, podemos assegurar que o Real vivido por estas mães na UTI implica Ser-aí na UTI; Cuidar e Caminhos de esperança.

\subsubsection{Ser-aí na UTI}

O homem é existência, é um ser no mundo, vinculado a uma espacialidade e temporalidade. Ser-aí é facticidade, traduzida em tempo e espaço; portanto é um ser histórico(6). A vida é entendida também como existência. Portanto, é através da vida, do estar-no-mundo, do relacionar-se com o outro, que o homem tem possibilidades de vir a ser e assumir a sua existência humana, manifestando a sua própria maneira de ser.

Tinha hora que precisava sair um pouco pra relaxar. Fazia bauzinho, florzinha, mas não conseguia ficar sem pensar nele. Sabia que elas cuidavam dele, mas nada como a mãe perto do filho, né? (M1)

A primeira vez que entrei lá, minha vontade era de não ficar. Queria ficar com o meu bebê, mas não com aquele monte de aparelho, então comecei a chorar, foi horrível. Agora não, tá melhor, mas não quero passar por isso nunca mais na minha vida (M4).

Foi muito ruim ter um filho na UTI, qualquer barulhinho, ficava preocupado, com medo de perder o... Qualquer sinal de dor, no rosto dele, me perguntava se o aparelho tava machucando, doendo (M5).

Lá assisti muita coisa, achava até que não ia suportar. Quando via meu filho sendo furado, tinha pena, mas não passava isso pra elas, porque quando elas viam que a gente tava nervosa, ficavam nervosa também e acabavam furando mais o bebê (M8). 


\subsection{Cuidar}

O cuidado materno é ação complexa, podendo ou não se manifestar e transcender as paredes de uma UTI, a partir do encontro com o outro; e ainda provocar uma multiplicidade de sentimentos e reações essenciais do ser-no-mundo, tais como sensibilidade, afeto e solicitude; o cuidar solícito é o estar-com. O cuidar, o relacionar-se com o outro, é a estrutura fundamental do Ser-aí, pois desenvolve as possibilidades de o ser-no-mundo relacionar-se consigo e com os outros;.cuidar significa compreender o ser, na sua relação com o outro( ${ }^{(5)}$. No mundo da UTI, algumas mães dizem que não sabem ou não podem fazer nada, porém, antes de se questionar tal comportamento, é importante visualizar os dois lados dessa interação humana. A mãe que cuida, quando necessita ser cuidada, e o bebê enfermo, que necessita desse cuidado para garantir a sua condição humana de ser-no-mundo, cada um como um ser único, com seus direitos e deveres dentro de um mundo existencial único - o mundo da UTI. Ajudava, tirava a temperatura, alimentava, banhava, trocava fralda, pegava no colo, não ficava parada. Gostava de fazer, de ajudar (M1).

Lá ajudo as meninas a cuidar da minha filha. Troco fralda, seguro pra trocar os panos. As vezes tiro a temperatura, desligo a bomba do soro, seguro a mão dela quando vão tirar o sangue, pra ela não ficar nervosa (M2).

As vezes conversava com ela, segurava pra tirar o sangue, trocava e uma vez coloquei no colo. Hoje ela tá com dreno na cabeça, mas eu troco, banho, dou leite, boto pra dormir, acalento, beijo, cheiro, abraço. E isso é muito bom, faz eu me sentir feliz (M3).

Quando ele tava acordado, abria a incubadora, conversava, pegava na mão e tentava ajeitar ele, quando tava torto. No meu braço, falava com ele e ele ficava olhando. Ah! Eu achava lindo (M4).

Lá troquei pouquíssima fralda, olhava, conversava, cantava pra ele, porque queria que ele ouvisse minha voz e soubesse que quem tava ali era a voz daquela pessoa que gostava de conversar e pegar na barriga, quando tava grávida (M6).

\subsubsection{Caminhos de esperança}

Ver um filho internado em uma UTI, entre a vida e a morte, dependente de vários aparelhos para sobreviver, representa quase sempre uma situação desesperadora. O caminho de esperança, portanto, tem se mostrado como uma das opções encontradas pelas mães para minimizar este sofrimento, bem como esta dor física e emocional. Por ser esse caminho um mundo compartilhado, vincula-se ao conceito heideggeriano de ser-com-outro. Os sentimentos de estar junto e de segurança são os principais construtores dos caminhos de esperança e podem ser significados como fatores de sustentação para o processo de cuidar e, em alguns casos, para o fenômeno da cura. A esperança, como visto, é o sentimento que mais estimula a mãe a lutar contra a doença do filho. Quando via que ele tava reagindo, me sentia melhor (M1). Ele sempre foi muito ativo. Ficava com os olhos....assim me olhando. E isso fazia eu me sentir melhor (M5).

Ficava ao lado dele conversando e ele ficava só olhando. Sentia uma emoção muito grande. Era pouco, mas ao mesmo tempo se tornava muito. Não podia fazer as outras coisas, mas tinha o olhar dele. E isso estimula muito a gente, muito mesmo, acredito que a ele também (M8).

A ser lançada no mundo da UTI, a mãe, desperta diferentes Sentimentos e emoções (perda dos direitos maternos, culpa, medo, bem-estar etc.)

\subsubsection{Sentimento de perda dos direitos maternos}

Observamos, por meio das convergências dos discursos, que a hospitalização parece fazer com que as mães percam o contato com o filho, que passa a pertencer mais ao corpo de médicos e enfermeiros do que propriamente à sua família. Tem hora que não deixam as mães tocar no filho, trocar a fralda. Aí é difícil, já que tô ali é pra ela sentir, que eu tô ali com ela né? (M2).

Você, sofre, dar amor, atenção, observa, mas não pode dar a assistência, que daria em casa. Você quer fazer, mas não pode. Elas dizem: não, deixa que a gente faz. Mas eu gostava de fazer, gostava de ajudar (M1).

Lá dentro da CTI é um pouco frustrante, é uma batalha. Lá, a mãe fica em segundo plano, não consegue participar, quem cuida do seu filho não é você e sim as enfermeiras, os médicos, os... Eles é que vão lutar pelo seu filho. Você fica só como se fosse arrodiando, assim [...] (M6).

É muito difícil, ser mãe na CTI, porque você não pode pegar no seu bebê. Elas não gostavam muito, Então aquela vontade...., Ainda mais eu que nunca tinha pegado nele antes, ficava assim, com aquela vontade de pegar, poder cuidar, banhar, de fazer todas aquelas coisas, né?" (M8).

\subsubsection{Culpa}

As emoções e os sentimentos da mãe são intensos ao ver seu filho recém-nascido lançado no mundo da UTI. Um dos sentimentos que aflora quando algo de mau acontece com o filho, é a sensação de culpa, pois este está relacionado com a responsabilidade pelo ser do outro.

Me sentia triste, angustiada [...]. Me sentia culpada, com uma grande responsabilidade. Achava que a culpa dela tá doente, passando por todo aquele momento, sofrimento, era minha, pois tomei uma caixa de Microvilar quando tava com 2 meses de grávida (M3).

Não me sinto na paz de vê ele cheio de aparelho, sinto tristeza de não ter ficado com ele na minha barriga os nove meses. Se ele tivesse na minha barriga tava mais protegido, não taria tão exposto. O pessoal pegando, furando. Não suporto ver furando ele. Choro (M4).

Me sinto triste, culpada, por ter ficado ligado nas minhas tristezas e problemas com o pai dela. Não imaginava que podia fazer tanto mal. Se tivesse deixado minhas tristezas de lado, talvez isso não tivesse acontecendo (M5).

\subsubsection{Encontro com a morte}

A possibilidade da morte, a falta de informações sobre os aparelhos ligados ao bebê, ou ao fato de não saber sobre o estado real do filho, são momentos difíceis e assustadores, chegando a produzir sentimentos e emoções confusos, desconfortantes e inesquecíveis.

Você vê menino grave, gravíssimo, morrendo um aqui outro ali, aí você olha pro seu filho e imagina ele naquela situação e vem aquele medo de que possa acontecer o mesmo com ele (M1).

Vai fazer 2 meses que tô com ela aqui e tô achando que ela tá recuperando, muito lento. Ela teve uma piora, teve uma parada, quando fui em casa, semana passada (M2).

Quando via uma criança piorando, ficava com medo do meu filho pegar uma infeção e piorar também. Uma vez vi 3 bebê morrer, quase morria do coração. A gente pensa que o nosso também vai morrer (M4).

Vê bebê morrendo, saturação baixando até o ponto de parar. Eu me sentia muito... Ficava muito triste. (silenciou e encheu os olhos de lágrimas)" Quando colocaram o oxímetro nela sem explicar, colocaram e pronto, pensei: Não! Minha filha tá muito grave. Pois eu tinha visto colocar num bebê que tava morrendo (M7).

\subsection{Modos de enfrentar a doença}

Os sentimentos de esperança e fé afloram como forma 
de impulsionar e/ou encorajar a mãe para o enfrentamento da doença do filho. Aparece como uma tábua de salvação ou como uma oportunidade existencial nova. Depois que conversei com você, chegou uma fé muito grande. Hoje creio que ela vai sair daqui boa (M3). Tem que ter muita fé em Deus. Quando vi que ele tava melhorando, fui me acalmando mais (M5).

Quando fui vendo, que a cada dia, ele tava reagindo, tirando um aparelho, se mexendo mais. Fui me sentindo mais forte. Hoje já me sinto mais confiante, Com a sensação de que tudo vai dar certo (M4).

Teve alguns dias que eu praticamente tinha perdido as esperanças, mas aí quando trocou a medicação [...] ela foi melhorando e hoje, já penso de outra maneira. Vejo tudo diferente (M7).

\subsubsection{Saúde e Doença / Vida e Morte}

O ambiente da UTI, bem como os difíceis e diversificados momentos de situações opostas de saúde e doenças/vida e morte, provocam ambigüidade de sentimentos e emoções em algumas mães. Às vezes achava que ela ia ficar boa, mas ao mesmo tempo, tinha medo dela morrer, não se salvar. A todo momento pensava nisso, aí chorava muito (M3). Cada melhora dela me alegrava, mas quando vinha a piora, parava de conversar com ela, voltava a minha tristeza (M7).

\subsubsection{Mudanças de comportamentos e hábitos}

Em alguns casos, mudanças de comportamento e/ou de hábitos vêm à tona. Só sei que E-6, nunca vai esquecer disso. É uma experiência que muda muito a gente. Perdi muito o orgulho, melhorei bastante (M6).

Hoje, depois de tudo, sinto que mudei muito, amadureci e vou mudar ainda mais. Vou procurar trabalhar pra sustentar meu filho, não vou obrigar ninguém a nada, nem pedir pensão. Penso que o pai dele tem obrigação de ajudar ou pelo menos de dar carinho, mas cabe a ele querer ou não (M8).

\subsubsection{Bem-estar ocasionado pelo apoio profissional}

A presença e a participação materna na UTI é considerada importante e indispensável para a recuperação do bebê enfermo, por transmitirem segurança e apoio ao recémnascido. Percebemos, ainda, que o carinho e o apoio do outro (profissional) junto ao ser-aí (mãe) lançado no mundo da UTI tem conseguido neutralizar o medo, a culpa, a ansiedade, o desconforto, dentre outros sentimentos maternos, causados pela hospitalização do filho enfermo, proporcionando sensações de bem-estar biopsicossocial à mãe acompanhante, facilitando a sua adaptação a esta nova realidade existencial e a relação ser-com na UTI, principalmente com o filho enfermo.

Umas meninas são ótimas, trata você de forma superespecial, entende a gente e isso melhora muito, melhora psicologicamente. Mas tem umas [...] Que vem com ignorância, como se a gente tivesse culpa dos problemas dela. A gente não tá bem, aí já viu, né? Quando vem aquela pessoa, doce, compreensiva, que conversa, aquilo entra no coração, vai melhorando, você vai ficando calma e ajuda a ver o filho de outra forma (M1).

Um dia fui ver ele com o pai, e nós ficamos... abismado. A enfermeira notou que a gente tava assim, tão passados, né? E veio falar com a gente. Conversou muito tempo aí acalmou mais um pouco (M6).

No dia que cheguei que ele tava no bercinho, fiquei feliz, lavei as mãos, deitei por cima dele e comecei a cheirá-lo. Aí a enfermeiras disse assim: Ih! Coisa boa é namorar de manhã bem cedo, em? São essas coisas que eu não esqueço (M6).

Na CTI, conversava com as outra mães, com as auxiliares. Conversa com todo mundo, mas tem aquela, que a gente pega uma confiança, né? Eu gostei muito da [...] ela me fez um favor e tanto. Ela conversava comigo, ela sempre me dizia que a " $E$ " ia ficar boa. $E$ isso era muito bom, me animava mais (M8).

A mãe acompanhante no mundo estressante e conflituoso das UTI's revelou-se como um ser-aí que necessita de apoio e solidariedade (ser-com), não somente dos parentes, mas, também e principalmente, da equipe e demais mães, para que possa encontrar energias para conviver com a doença e tratamento de seu filho. Pois um ser é dado em conjunto, o mundo é sempre um mundo compartilhado. O ser-em é sempre sercom os outros ${ }^{(6)}$. A mãe acompanhante, como todo ser, necessita de apoio, compreensão e oportunidade de comunicação para refazer seu mundo-vida, reconstruir sua comunidade existencial, dentro das imposições dessa nova realidade, e evidenciar-se como um ser-com-outro dentro do mundo da UTI. Os aspectos relacionais (ser-com profissionais, componentes familiares e demais mães acompanhantes), conforme visto, foram referidos pelos sujeitos envolvidos como elemento fundamental para o enfrentamento desta nova realidade, por estabelecer um clima de solidariedade e confiança.

\subsection{Ser-com profissionais (relação mãe-profissional no mundo da UTI)}

As mães vêem na compreensão, apoio e ajuda da equipe o caminho para enfrentar o longo e difícil tratamento de seus filhos. O estar-próximo deste outro, compartilhando seus momentos de dor, parece produzir nessas mães um sistema de apoio semelhante ao estabelecido no mundo da família.

Uma das meninas me deu o maior apoio, conversou comigo, disse que eu não chorasse, entregasse na mão de Deus, que ele resolvia. Depois da conversa fiquei mais aliviada e me alegrei muito (M3).

Quando cheguei lá achei ruim, depois fui conversando com as enfermeiras, médicos [...] aí fui melhorando, mas nunca que a gente se acostuma totalmente, né? (M4).

Foi muito importante o apoio dessas pessoas lá dentro. Isso é fundamental nesse momento. Você ver seu filho quase morto como eu vi, aí a enfermeira chega, aplicar o remédio sem dar nem uma atenção a você que tá,ali, muito frágil. Num é fácil não. Quando elas são gentis, conversam, brincam com o seu filho, Isso daí deixa a gente se sentir melhor (M6).

No entanto, é com o médico que elas estabelecem maior relação de confiança, pois acreditam que seus procedimentos são os mais necessários para a recuperação de seu filho enfermo.

O médico devia ao examinar, dizer se ele tá sentindo ou não alguma coisa. Tinham algumas pessoas lá que me mostrava o que tava acontecendo. Mas se fosse o médico, a gente se sentia mais tranqüilizada (M5).

Era muito bom, me animava quando o médico examinava, olhava o prontuário e me dizia num português que eu entendia, que ele tem um problema respiratório grave, mas que com o tempo vai acabando e ele vai se recuperando (M6).

\subsubsection{Ser-com demais mães acompanhantes}

As mães, por encontrarem-se frágeis, sensíveis à dor neste momento, estabelecem uma relação solidária entre si, compartilhando dúvidas, sentimentos, fragilidade, valores materiais e dificuldades impostas pela enfermidade do filho, e acabam por criar vínculos que ultrapassam os portais do mundo hospitalar.

Umas mães lá, me dava conselho e isso ajudava muito, muito mesmo (M3)

Conversava com as colegas sobre a família, o bebê, a situação do filho, os médicos, as enfermeiros. A gente dizia, quando elas eram chatas, tomara que ela já vá embora, que já chegue a hora dela ir e chegar a fulana (M4). 
Do lado que fiquei tinha 3 mães. A gente ia conversando, conhecendo um pouco dos problemas de cada uma e a cada dia, a gente ia se conhecendo melhor. Rezava, pedia a Deus pra sair dali o mais rápido possível. Até hoje, ainda mantenho contato com alguma dessas mães (M6).

\subsection{Ser-com componentes familiares no mundo da UTI}

A doença desarticula e faz aflorar diferentes sentimentos na relação familiar. A estrutura e/ou dinâmica familiar modificase radicalmente perante o mundo hospitalar e a nova rede de relações lá existente. A família passa a viver outra dimensão existencial, provocando conflitos, desencontros e rupturas, por vezes irreversíveis. A situação agrava-se quando a mãe precisa deslocar-se de sua cidade para acompanhar o tratamento do filho, pois podem surgir problemas emocionais, sentimentos de medo, solidão e/ou de abandono e ocorrer uma transformação no modo de ser desta mãe. Lá não tinha ninguém da minha família. Fiquei sozinha com ele, 3 meses. Sentia falta da minha mãe, de uma amiga pra conversar. Aí eu conversava com o "M" (M1). Tem hora que dar um pouco de estresse. Dar saudade de casa, pois não é fácil ficar com o filho aqui muito tempo, longe da família (M2). Quando chegava em casa conversava com o meu marido e ele sempre dizia, tu não perguntou isso, pergunta isso. $E$ isso me ajudou muito (M5). Aqui tô sozinha, não recebi nem um telefonema e nem uma visita até agora. Eu sinto muita falta disso (M7).

Quando ligo pra casa, meu pai e meu marido, pergunta como é que tá o neném. Meu pai num pergunta nem por mim. Falo como ele tá e eles ficam morto de feliz, louco pra vê ele, mas como a gente mora no interior, fica mais difícil de vir pra cá. E também tem que trabalhar pra mandar dinheiro pra mim, né? Então fica mais difícil (M4).

Quando você chega em casa, que as pessoas perguntam como é que ele tá. Você diz confiante e feliz que ele tá bem melhor. Aí no outro dia, você já voltava bem melhor e mais confiante (M6).

\subsubsection{Ser-com o filho enfermo no mundo da UTI}

A relação mãe-filho foi considerada valiosa pelos sujeitos envolvidos, por gratificar o bebê enfermo e a própria mãe. A trama dessa relação desvelou-se assim: É muito importante que a mãe fique com o filho. Muitas crianças choram, acho que é sentindo falta da mãe. Se ela ficar ali dando carinho, talvez o filho se sinta melhor (M2). Quando cheguei na CTI não conversava com ela, segurava só na mãozinha. Depois que comecei, ela melhorou e foi pro $\underline{A}(\mathrm{M} 3)$.

Acho que agora sou mais mãe. No começo, sentia medo. Sinto medo ainda, de pegar no bebê, mas adoro quando consigo fazer isso. Eu acho ótimo. Se eu gosto, ele tem que gostar também né? (M4).

Acho que, a minha presença, foi muito bom pra ele. As meninas diziam: basta você sair, que ele começa a chorar, parece que sente. Com certeza ele sente. Pois, quando chegava que passava a mão nele, ele abria o olho, e depois voltava a dormir de novo. Logo também, ficava sempre pegando nele, beijando, conversando com ele, então ele ia mais e mais conhecendo a mãe (M8).

\section{Estrutura do fenômeno situado}

As principais categorias encontradas neste estudo foram: Ser-mãe na UTI, Real vivido no mundo da UTI, Sentimentos e emoções e Aspectos relacionais. Estas foram trabalhadas, com o propósito de obter as convergências das unidades de significado importantes para mostrar a estrutura do fenômeno Vivências maternais em UTI. Apreendemos, a partir dos resultados, que Ser-mãe na UTI é participação, nervosismo, medo, ocupação, estresse. É estar junto para se fazer perceber, aprender a cuidar e para dar força e apoio ao filho, quando o desejo maior é estar longe. É conversar, dar carinho e amor, mesmo estando coberta de medos. É observar, ter paciência e muita fé em Deus, quando ainda não lhe é permitido fazer nada. É ter que batalhar, lutar pelo filho, quando também tem necessidades de cuidado. É assumir a condição de supermãe, quando está carente de energias, em razão da complexa e difícil situação existencial na qual se encontra. É preocupação, pois, embora ocupada com o outro, alimentando, vestindo, tratando do corpo doente ou estando junto, estar indo ao encontro da pré-ocupação, pois preocupar-se, é estar na dimensão última do ser, como uma constituição ontológica da pre-sença que se encontra imbricada, não somente no mundo da ocupação com o outro, como também no mundo dela própria(6)

Com relação ao real vivido no mundo da UTI, podemos observar que geralmente o cuidar se encontra na essência materna. No entanto, o sentimento de esperança acaba, por vezes, interferindo no modo de ser e agir desse Ser-aí, influenciando-o ou não a lutar e/ou envolver-se com o cuidar do filho enfermo. Percebemos, ainda, que este cuidar materno pode mostrar facetas contraditórias e significar, como oportunidade de aprendizado ou forma de promover o próprio desenvolvimento pessoal e/ou bem-estar do outro. Alguns discursos referem-se ao cuidar materno como algo constante e predominante na UTI; no entanto, há sujeitos que referem temor, diante da simples possibilidade de cuidar do filho recém-nascido, que se encontra ligado por fios a diferentes aparelhos; e sujeitos que falam sobre as dificuldades e entraves encontrados para realizar o cuidar materno na unidade hospitalar e ainda sobre seus sentimentos ao verem seus filhos enfermos sendo cuidados por especialistas, no lugar da própria mãe.

O cuidar harmoniza-se como simples ocupação ou transcende o existencial, indo ao encontro da pré-ocupação( ${ }^{(6)}$. Nesta pesquisa, o cuidar materno mostra indícios de préocupação com o outro, pois transcende o simples ato de cuidar. Porém, em alguns casos, esse cuidar é significado como simples possibilidade de ocupação, quando se restringe ao ôntico, que enxerga o cuidar como um dever para com o outro, sem nenhuma relação ou integração interpessoal. E essa mãe acaba por cair no falatório, na tagarelice, na ambigüidade. O falatório, não tem a intenção de enganar, é apenas um modo inautêntico de o ser manifestar-se, por estar preso ao ôntico, modo de ser da presença protegido pelas evidências e pela autocerteza mundana, sem enxergar as possibilidades do ponto de vista ontológico de seu ser(6).

A mãe, ao ser lançada repentinamente em um mundo de perdas, sofrimentos e inseguranças, enfrenta riscos que a fazem explodir em uma diversidade de sentimentos e emoções que variam entre culpa, pena, medo, perplexidade, tristeza, solidão, esperança, impotência, dentre outros. O ser-em é sempre ser-com os outros e o ser-em-si intramundano destes outros é co-pre-sença( ${ }^{(6)}$. E é nesse modo de encontro com a doença do filho, com o ambiente da UTI (onde há convivência com profissionais e outras mães, durante momentos traumáticos ou de cuidados de higiene e de alimentação do bebê), que os sentimentos maternos, bem como seus modos determinados, se revelam provocando um retorno ao ontológico.

A CTI é muito estressante. Se pudesse tinha pego o " $M$ " e levado pra casa. Você vê seu filho sofrendo aí sofre também. Pois você não pode dar aquela assistência que daria em casa (M1)

Lá dentro é muito ruim, é péssimo, porque a gente vê a filha da gente ser furada todo dia pra ser medicada. Os aparelho me deixavam um pouco com medo de pegar na minha filha. De pegar a doença dela não, jamais (M3).

Lá dentro, você fica sobre tensão, vive impressionada. Você sente um aperto no coração. Uma coisa muito ruim. Nunca pensei que tivesse tantos bebê assim, na incubadora e com muitos aparelho. Me impressionei. 
Não sabia que existia esse mundo aparte fora do que a gente vive (M5).

Olha, não sei não, Deus que me livre. Você adoece, só vê, todo santo dia, furar a cabeça braços e pés do seu filho. Na CTI perdi muitas coisas, não amamentei, não peguei ele no colo, não senti aquele cheirinho de neném, pois ele tinha cheiro de CTI (M6).

Foi muito difícil, pois imaginava que ele ia pra casa quando nascesse e de repente quando chegou o dia, ele vai é pra UTI e fica naqueles aparelhos. Me sentia muito mal , muito nervosa, as vezes achava que não ia agüentar vê-lo daquele jeito (M8).

Ao examinar esses discursos, percebemos que a mãe acompanhante necessita de apoio e ajuda para atingir a sua constituição ontológica existencial, importante para uma boa condição biopsicossocial de ser-aí no mundo da UTI, pois é a partir do ser-com e para os outros que subsiste a relação ontológica entre as pre-senças. Quando a pre-sença não se volta para os outros, por acreditar não precisar deles, ou ainda, por achar o outro dispensável, esta se mantém nos modos deficiente ou indiferente de ser-com, pois o ser-com, como constitutivo existencial do ser-no-mundo, necessita da compreensão dos outros, para não cair na ocupação. O sercom-os-outros pertence, portanto, ao ser da pre-sença, que, sendo, põe em jogo o seu próprio ser.

\section{Reflexão sobre a estrutura do fenômeno situado}

O trabalho empírico que ofereceu argumentos para a sustentação deste ensaio revelou que a mãe na UTI se apresentou como um ser com o outro, angustiado, temeroso, porém autêntico, que se inquietou, lutou pelo filho enfermo e participou, quando possível, de seus cuidados, sofrimentos e sucessos, enfim, de sua luta pela vida, mas também como um ser-com, que saiu de seu existencial, ou seja, da simples ocupação, e foi ao encontroa da pré-ocupação, manifestando sentimentos de angústia e incertezas; e ainda, trouxe contribuições valiosas para a elucidação de um novo paradigma de convivialidade no mundo das UTI's e um possível caminho para resgatar a essência humana e articular novas diretrizes para o clarificação de uma prática assistencial cada vez mais humanizada nas instituições de saúde. Essas mudanças, no entanto, não acontecem facilmente, sem obstáculos, pois implicam luta, solicitando a ocorrência de libertação da assistência tradicional, racional, imediatista, setorizada, controladora, no contexto da qual o homem é cuidado segundo os critérios de corpo sadio e corpo doente, sem valorização da trajetória existencial da mãe acompanhante, marcada pela experiência da angústia comum a todo ser-no-mundo.

\section{Referências}

1. Scochi CGS, Nogueira FS, Pereira FL, Brunherotti MR. Programa para pais de bebês de risco: contribuição para formação do aluno de enfermagem. Revista Brasileira de Enfermagem, Brasília (DF) 2002 jan/fev;55(1):36-43.

2. Barguil $P M$, Leite RCM. Voltemos às próprias coisas: o convite da fenomenologia. In: Barreto JAE, coordenador. Imaginado erros: escritos de Filosofia da Ciência. Fortaleza (CE): Casa José de Alencar; 1997. 206 p. p. 79-111 (Alagadiço novo).

3. Ministério da Saúde (BR). Conselho Nacional de Saúde. Diretrizes e normas regulamentadoras de pesquisas envolvendo seres humanos: resolução no 196/96. Brasília (DF); 1996. 12 f. Disponível em: URL: <http://www.ufrgs.br/hcpa/gppg/res19696.htm>. Acessado em: 11 mar 2003.

4. Martins J, Bicudo MAV. A pesquisa qualitativa em psicologia: fundamentos e recursos básicos. $2^{\mathrm{a}}$ ed. São Paulo: Moraes; 1994. 110 p. il.

5. Heidegger M. Todos nós... ninguém: um enfoque fenomenológico do social [tradução de Dulce Maria Cristalli]. São Paulo: Moraes; 1981. $72 \mathrm{p}$.

6. Heidegger M. Ser e tempo. $3^{\mathrm{a}}$ ed. Petrópolis (RJ): Vozes; 1993. 2 vol.

7. Boff L. Saber cuidar: ética do humano, compaixão pela terra. $2^{\mathrm{a}} \mathrm{ed}$. Petrópolis (RJ): Vozes; 1999. 199 p.

Data de recebimento: 12/09/2002

Darta de aprovação: 20/08/2003 